\title{
Interactions between silicate and salt melts in LBA glass-making
}

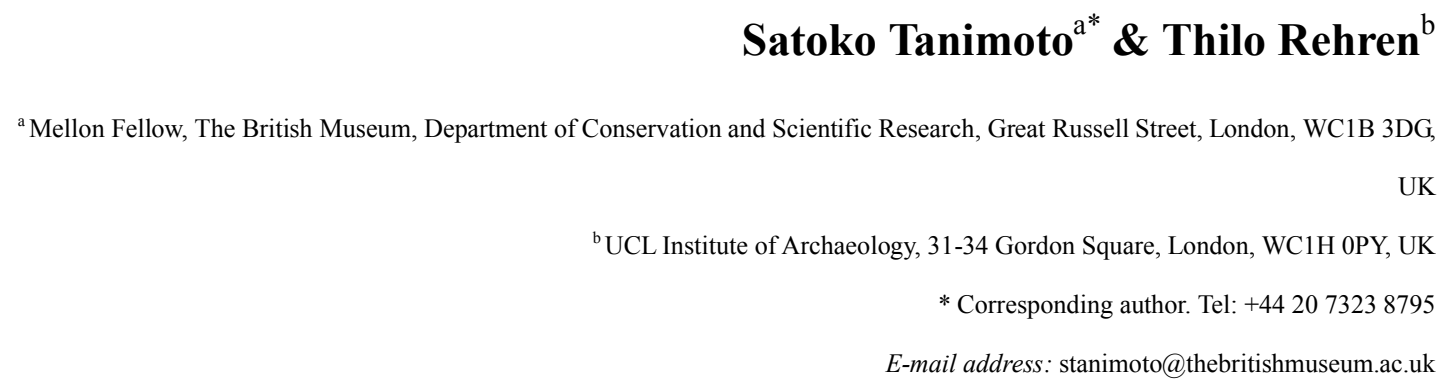

Keywords: glass, Late Bronze Age, Egypt, Mesopotamia, alkali, chloride, salt

\begin{abstract}
A series of glass-making experiments have been done to explore the influence, if any, of the presence of alkali chlorides in a typical soda-lime-silica glass batch on the final composition of the glass. The experiments have shown that concentrations of chlorides up to the limit of solubility of chlorine in the melt are actively contributing alkali ions to the glass-forming process, and that at higher chloride concentrations in the batch a separate salt melt forms, known as galle. At equilibrium conditions, the alkali ratio in the galle is different from the initial alkali ratio in the batch and differs from the ratio in the co-existing silicate melt. Significantly, there is full exchange of alkali ions between the two melt systems and the addition of pure potassium chloride to a batch containing pure sodium carbonate (= soda ash) results in the formation of a mixed alkali glass and a mixed alkali galle, with complementary alkali ratios. The alkali earth elements (i.e. calcium and magnesium), in contrast, are not taking part in these ion exchange reactions, and seem not to be affected by chlorides present in the batch. These findings are particularly relevant when comparing analyses of different plant ashes with archaeological glasses; the alkali ion ratios between ash and glass are only likely to be similar when no galle is forming together with the glass melt; in the presence of more than a few weight percent of chlorides in the batch, it is likely that the alkali ratio in the glass will be increasingly shifted away from the total alkali ratio in the batch as the chlorine content increases. While the argument
\end{abstract}


is developed specifically for Late Bronze Age halophytic plant ash glasses, the results are likely to be valid in principle also for any other glasses based on halogen-rich batches and containing more than one alkali metal.

\section{Introduction}

Very little is known about glass-making during the Late Bronze Age (LBA), despite numerous fragments of glass being discovered from archaeological sites of that period, both in Egypt and Mesopotamia. Most information on ancient glass-making is deduced from chemical analyses of finished objects and possible raw materials, such as mineral natron and plant ashes. These indicate that most likely plant ash was the flux used during this period (Turner 1954b, 1956a, 1956b; Brill 1970: 111; Sayre and Smith 1974; Lilyquist et al. 1993). Vegetable ash compositions are rather heterogeneous in their composition, particularly as regards their ratios of soda $\left(\mathrm{Na}_{2} \mathrm{O}\right)$ to potash $\left(\mathrm{K}_{2} \mathrm{O}\right)$ and lime $(\mathrm{CaO})$ to magnesia $(\mathrm{MgO})$. Another important factor is the amount of non-reactive compounds such as sulphates and chlorides present; the latter can reach $50 \mathrm{wt} \%$ of the total ash content (Turner 1956b; Brill 1999b; Busz and Sengle 1999; Jackson and Smedley 2004; Jackson et al. 2005; Tite et al. 2006). The presence of these non-reactive components in the ancient glass batch has been known for centuries and much industrial research and development has focussed on making these salts either useable for glassmaking or to reduce their presence in the batch. Turner (1956b) was probably the first to point out their presence in ancient glass-making, indicating that this aspect is of potentially real significance. However, to our knowledge no systematic study of their influence on the composition in the co-existing glass melt has been published, probably because very little chloride is present and galle formation does not occur during the typical modern soda-lime-silica (SLS) glass melting process. 
Diagnostic indicators to distinguish whether mineral natron and plant ash flux have been used to make glass are, in particular, the levels of magnesia and potash in the glass, with typical mineral natron-based glasses thought to have less than about one percent of each, and most plant ash-based glasses having between two and four percent of each of these two oxides (Lilyquist and Brill 1993). This tight chemical clustering of culturally defined glass groups is implicitly often seen as reflecting conservative batch mixtures and generally a very tight control over raw material supply and selection. More recently, it had been argued that, as much as they differ from each other, both LBA and Roman glasses are chemically too homogeneous within each of the two groups across long chronological periods, vast geographical regions, and different colours, to directly reflect in their composition the highly variable raw materials available (Rehren 2000a, 2000b). Instead, it is assumed that certain factors inherent in the glassmaking procedures may have had a regulating effect on the resulting glass composition, reducing the compositional variability of the raw materials. In particular, it had been shown that under (near) equilibrium conditions, the total amount of alkali earth oxides in the glass melt is governed by the melting temperature, provided that an excess lime-rich phase such as the parting layer is in direct contact with the melt (Rehren 1997; Shugar and Rehren 2002; Schoer and Rehren 2007; Tanimoto 2007). Under these conditions, the magnesia content is likely to be capped at near $4 \mathrm{wt} \%$, as experimentally determined by Owen-Illinois (1944), and indirectly confirmed for most LBA glasses by their suspiciously constant levels of around $4 \mathrm{wt} \%$ MgO. Thus, alkali earth oxide concentrations in LBA glasses are controlled to a considerable degree by the inherent melting behaviour of the system, and the configurational parameters such as melting temperatures and the use of lime-rich parting layers and small vessels with a proportionately large contact area between the parting layer and glass melt (Rehren 2008). 
This paper now investigates possible factors that affect the alkali oxide composition of the finished glass under conditions thought to represent LBA glassmaking practice. Of particular interest is the role, if any, which nominally non-reactive salts such as sulphates and chlorides assume during glassmaking, and whether the relatively constant levels of potash in most LBA glasses can be interpreted to represent similar constant raw material composition. This has direct significance for the archaeological interpretation of glass compositions, including the discussion of centralised vs. regional glassmaking, and raw material selection. We therefore tested the behaviour of different alkali compounds in the glassmaking process, allowing two distinct melts to form from the batch; a silica melt, that is the glass proper, and a salt-rich phase, traditionally known as galle, and in our experiments composed solely of chlorides. Glass and galle form a system of two immiscible melts, like oil and water, which is why we call this the Two Melt Model. Particular emphasis is placed on the influence of the presence of galle on the ratio of soda to potash in the silicate melt, on the relative availability of sodium and potassium for glass-forming when they are provided as either carbonate or chloride, and whether the salt could act as a buffer or reservoir for alkali ions, interacting with the silicate melt. The idea behind this hypothesis is that while alkali ions are readily accommodated in both silicate and chloride melts, there may be a differential preference for one alkali ion over the other to enter the silicate melt, assuming ion exchange between the two phases takes place during the melting.

There are only few published studies on chlorine solubility in glass and the distribution of alkalis between glass and salt melts. Bateson and Turner (1939) tested the maximum solubility of sodium chloride in SLS glass (containing $9.2 \mathrm{wt} \% \mathrm{CaO}$ and $15.8 \mathrm{wt} \% \mathrm{Na}_{2} \mathrm{O}$ ) by preparing samples with various amounts of excess salt added to the batch, and fired at $1400{ }^{\circ} \mathrm{C}$. They determined that there is a maximum chloride $(\mathrm{Cl})$ content in their glass regardless of the amount of salt added, of $1.42 \mathrm{wt} \% \mathrm{Cl}$. This indicates that the chlorine 
content is controlled by the limited solubility of chlorine in the silicate melt rather than the batch composition. More recent work by Köpsel (2001) and Shugar and Rehren (2002) has come to similar results, and also indicating that the calcium content of the melt is of greater significance for chlorine solubility than the sodium content or the melting temperature. This latter observation contradicts theoretical expectations (Freestone pers. comm.) and may require further research to explain. Bateson and Turner (1939) did not explore the role of potassium under these conditions, probably because this is not relevant in modern glassmaking. More recent studies are concerned with the evaporation of alkalis during glass melting, both to understand and minimize corrosive attack on the furnace refractories, and to minimize halogen emissions into the environment (Beerkens 2001; Beerkens and Verheijen 2005). Gerth et al. (1998) have used evaporation studies to investigate medieval glasses; however, most of these studies concern firing temperatures of 1300 to $1500{ }^{\circ} \mathrm{C}$, far in excess of pre-medieval glassmaking temperatures. We assume that the upper operating temperature for LBA glass furnaces was in the range of $1100^{\circ} \mathrm{C}$ (Rehren and Pusch 2005), not least due to the lack of more fire-resistant building materials. Alkali and halogen evaporation at these temperatures are thought to be too slow to have a significant effect on the resulting glass compositions, and are thus not further considered here.

\section{Methodology}

The intention of this study was to operate within the technical conditions as assumed for LBA glassmaking. However, direct archaeological evidence for glassmaking at present is restricted to the site of Qantir-Pi-Ramesse (Rehren and Pusch 2005, Pusch and Rehren 2007) with further evidence for glassmaking in Amarna (Petrie 1926; Turner 1954a). All other published LBA sites with glass workshop evidence, including the vast majority of finds from Amarna, concern glass working, i.e. the production of artefacts from existing glass, or the exchange of glass ingots. Textual evidence for glassmaking, primarily the Mesopotamian cuneiform tablets that are well studied and interpreted (Oppenheim et al. 
1970), is of limited practical value for the research questions at hand. Therefore, we modelled our glass composition on an average LBA base glass, and limited the melting temperatures to $1050{ }^{\circ} \mathrm{C}$. This temperature is within the range at which the Nile silt-based ceramic vessels used in glass melting are mechanically still stable enough to function, as demonstrated by Turner (1954a), and represents the upper limit of melting temperatures indicated by the chemical compositions of LBA glasses when plotted into the appropriate ternary diagram (see below, Fig. 1).

Several series of experimental melts were prepared using chemical-grade raw materials. Different batch compositions of glasses were prepared using modern raw materials, namely silica $\left(\mathrm{SiO}_{2}\right)$ sand, calcium carbonate $\left(\mathrm{CaCO}_{3}\right)$, soda ash (mainly sodium carbonate, $\left.\mathrm{Na}_{2} \mathrm{CO}_{3}\right)$, magnesium oxide $(\mathrm{MgO})$, sodium chloride $(\mathrm{NaCl})$, and potassium chloride $(\mathrm{KCl})$.

All the raw materials used were oven dried at $110^{\circ} \mathrm{C}$ for 2 hours to remove any moisture and subsequently stored in a desiccator with silica gel. Batches were weighed in to achieve $100 \mathrm{~g}$ of final glass and the raw materials thoroughly mixed in a plastic bag. Mullite crucibles were used to reduce the interaction between the vessel and the formed glass.

The filled crucibles were heated in an electrical furnace with heating filaments in the sidewalls at the rate of $3{ }^{\circ} \mathrm{C} /$ minute from room temperature to the selected melting temperature in order to prevent the crucibles from fracturing during heating. Three crucibles were placed in a single row inside the furnace to allow even heating from all sides. For primarily technical reasons, a typical melting time of 16 hours was chosen, which allows the furnace to reach the melting temperature after about 6 hours of heating. Shugar and Rehren (2002) tested extended melting times of up to 40 hours to check whether these would have a significant effect on the resulting glass; no such effect was observed, reflecting the small batch sizes and indicating that equilibrium was reached. After melting, the furnace was allowed to cool to room temperature with the crucible still 
inside the furnace for a further 2 hours to reduce mechanical stress in the glass.

A single primary batch composition ("Base A") was selected for all of these experiments, to fall into the soda-rich cotectic trough of the SLS ternary diagram at $5 \mathrm{wt} \% \mathrm{MgO}$, shown here as Fig. 1 (after Shahid \& Glasser 1972: 32; Figure 3). This batch composition had an ideal or set melting temperature as taken from the liquidus surface of the ternary system, of $1000{ }^{\circ} \mathrm{C}$. The batches were then fired at $1050{ }^{\circ} \mathrm{C}$ to assure the materials are fully reacted.

In order to produce $100 \mathrm{~g}$ Base $\mathrm{A}$ glass of the desired composition ( $65 \mathrm{wt} \% \mathrm{SiO}_{2}, 19.5 \mathrm{wt} \%$ $\mathrm{Na}_{2} \mathrm{O}, 10.5 \mathrm{wt} \% \mathrm{CaO}$ and $\left.5.0 \mathrm{wt} \% \mathrm{MgO}\right), 65.0 \mathrm{~g}$ of silica sand, $18.8 \mathrm{~g}$ of calcium carbonate, $33.3 \mathrm{~g}$ of soda ash, and $5.0 \mathrm{~g}$ of magnesia were mixed.

Three different base compositions were then mixed, derived from Base A. These have the same concentrations for $\mathrm{SiO}_{2}, \mathrm{CaO}$, and $\mathrm{MgO}$, but different alkali contents. Bases A-4 to A-6 have an increasing amount of sodium replaced by potassium, equivalent to 0.5 to 2.5 wt $\% \mathrm{~K}_{2} \mathrm{O}$, but with the potassium always added as $\mathrm{KCl}$ (Series 2-1). For this, a conversion factor of 1.58 was used, i.e. $3.95 \mathrm{~g} \mathrm{KCl}$ were added to the batch to achieve $2.5 \mathrm{wt} \% \mathrm{~K}_{2} \mathrm{O}$ to allow for the lower relative amount of potassium in $\mathrm{KCl}$ compared to $\mathrm{K}_{2} \mathrm{O}$. At the same time, the amount of $\mathrm{Na}_{2} \mathrm{CO}_{3}$ added to the batch was reduced as the amount of $\mathrm{KCl}$ increased. Different amounts of alkali chloride were then added to these three base glass batches. Series 2-2 to 2-4 had 10, 20 and $50 \mathrm{~g} \mathrm{NaCl}$ added, while Series 2-5 to 2-7 had 10, 20 and $50 \mathrm{~g} \mathrm{KCl}$ added, respectively.

The composition and homogeneity of the formed glass was determined by electron microprobe, using a JEOL superprobe JXA 8600 with an accelerating voltage of $15 \mathrm{kV}$. A current of $6 \times 10^{-8} \mathrm{~A}$ was used to guarantee sufficient count rates and statistical reliability of the data. The seven "base glass oxides" (Lilyquist and Brill 1993: $\mathrm{Na}_{2} \mathrm{O}, \mathrm{K}_{2} \mathrm{O}, \mathrm{MgO}$, 
$\mathrm{Al}_{2} \mathrm{O}_{3}, \mathrm{SiO}_{2}, \mathrm{CaO}$, and $\mathrm{Fe}_{2} \mathrm{O}_{3}$ ) were determined. Aluminium and iron were included to check for contamination from the crucible and raw materials; their concentrations were typically below the detection limit of the instrument used. To avoid soda loss during analysis, area-scan analyses at x 800 magnification, covering approximately $110 \mu \mathrm{m} \times 80$ $\mu \mathrm{m}$ were conducted. This kept the absolute analytical error for soda to less than one percent, and often less than half of one percent by weight below the expected value for Corning $\mathrm{A}$ and $\mathrm{B}$ glasses, with concentrations of 14 and $17 \mathrm{wt} \%$ soda respectively. Analytical accuracy was tested by analysing two different certified SLS glass standards, DGG 1 and DGG 2 (Table 1) together with the unknowns. The results show that the data is accurate to within a few percent relative for the major and minor oxides, and that the analytical error is lower than the overall error in the preparation of the glass batches.

\section{Melt formation and phase separation}

Full formation of glass occurred in all series of melts, but the degree of separation between glass and galle differs from sample to sample. Most of the melts produced a residual salt phase that solidified as a discrete layer above the glass. The separation of glass and galle was typically good enough to allow mechanical separation, especially when more than about $1 / 6$ of the batch consisted of salt (Fig. 2a, b). Only melts containing an initial amount of less than $1 \mathrm{~g} \mathrm{Cl}$ did not produce a separate salt layer but formed a clear glass phase without any visible salt phase. Melt A-6, which contained $1.4 \mathrm{~g} \mathrm{Cl}$ as $\mathrm{KCl}$ in the batch, had some opaque salt phase over the transparent glass, which was almost impossible to separate mechanically.

\section{Results}

The analytical results are typically in close agreement with the weighed-in batch compositions; some minor discrepancies occur, particularly for silica and lime, which may be either due to incomplete equilibrium conditions or homogenisation of the analysed 
samples, analytical uncertainties, or weighing-in errors. However, the data is considered robust and consistent enough to permit meaningful interpretation. Analysis of a typical Base A glass which had no salt added to the batch resulted in $65.3 \mathrm{wt} \% \mathrm{SiO}_{2}$ (weighed in target was $65.0 \mathrm{wt} \%$ ), $18.5 \mathrm{wt} \% \mathrm{Na}_{2} \mathrm{O}$ (target $19.5 \mathrm{wt} \%$ ), $10.9 \mathrm{wt} \% \mathrm{CaO}$ (target $10.5 \mathrm{wt} \%$ ) and $4.8 \mathrm{wt} \% \mathrm{MgO}$ (target $5.0 \mathrm{wt} \%$ ). In addition, $0.2 \mathrm{wt} \% \mathrm{~K}_{2} \mathrm{O}$ and $0.1 \mathrm{wt} \% \mathrm{Al}_{2} \mathrm{O}_{3}$ were found, probably contamination from the crucible material. Chlorine was analysed in this sample at around $0.025 \mathrm{wt} \%$, at the limit of analytical reliability for the electron microprobe.

In Series 2-1, that is the base glasses A-4 to A-6 with just a few percent potassium chloride added to replace sodium, the potash content mirrors closely the amount of potassium added as potassium chloride (Table 2). The chlorine content of the glass is slightly higher than expected; Base A-4 had $0.3 \mathrm{~g} \mathrm{Cl}$ added as $\mathrm{KCl}$, and the resulting glass has $0.4 \mathrm{wt} \% \mathrm{Cl}$. Base A-5 had $0.9 \mathrm{~g} \mathrm{Cl}$ added, while the glass analysis showed $1.2 \mathrm{wt} \% \mathrm{Cl}$, indicating either analytical uncertainty, or that there is another source of chlorine in the batch than the added $\mathrm{KCl}$. It is unlikely to be impurities in the raw materials, as demonstrated by the analysis of the salt-free Base A glass. Base A-6, which contained an estimated $1.4 \mathrm{~g}$ of $\mathrm{Cl}$ in the batch added as $\mathrm{KCl}$, produced a glass with the same $1.2 \mathrm{wt} \% \mathrm{Cl}$ as Base A-5, despite more chlorine being available in the batch. Instead, it showed small amounts of galle forming (see above). Similar results were consistently observed in other experiments, not reported here, indicating that for this particular composition the total chlorine content is capped somewhere near 1 to $1.5 \mathrm{wt} \% \mathrm{Cl}$ (Tanimoto 2007). This is in excellent agreement with earlier data published by Bateson and Turner (1939), and with chlorine concentrations typically observed in ancient glasses.

In addition to confirming the previously known existence of a cap in chlorine solubility, this result has shown that potassium chloride is not non-reactive in glass-making. However, its direct contribution to glass-forming is limited by the amount of chlorine which can be absorbed into the glass, and the molar equivalent of potassium. Any additional potassium 
chlorine will not be incorporated into the glass. Given the low melting temperature used, it is unlikely that much chlorine will leave the system as gas. Instead, it is likely to form galle, as visually observed. For the salt melt to form, it requires a stoichiometrically defined matching amount of metal ions, and therefore no further metal ions are added to the silicate melt. X-ray fluorescence (XRF) analyses of the excess salt phase from our experiments have shown that these metal ions are invariably alkali metal ions and not alkali earth metal ions (Tanimoto 2007). Thus, any effect the presence of a co-existing chlorine melt has on the composition of the glass melt is likely to be restricted to the alkali metals, not affecting the alkali earth metals.

Further series of experiments were done to explore the effect of larger quantities of salt in the batch, particularly whether there is an exchange of ions between the melts. If this is the case, we wanted to know whether the alkali ratio is the same for both melts, or whether one alkali metal has a stronger affinity to the salt melt than the other, and is accordingly depleted in the silicate melt. Series 2-2 to 2-4 explore how the amount of excess sodium chloride has an effect on the potash uptake in the glass, and whether there is a threshold value of potash in the glass which can not be removed ('washed out') unless unrealistically high sodium chloride quantities are assumed.

The earlier results (Series 2-1, above) had shown that for low concentrations, if there is no additional $\mathrm{NaCl}$ in the initial batch, all of the potassium in the batch present as potassium chloride goes into the glass phase even if the solubility of chlorine in the silicate melt is exceeded. The situation changes with the addition of sodium chloride (Table 2); additional $\mathrm{NaCl}$ in the batch decreases the amount of potassium that goes into the glass phase (Fig. 3). Two fundamental observations stand out: the higher the initial potash level is, the more affected it is in absolute terms compared to those with a lower initial potash level, and the more common salt is present, the less potash enters the glass. 
A remarkable feature is the amount of potassium that enters into the glass as a proportion of the total alkali metals present in the batch as chlorides. Base A-4 with $10 \mathrm{~g} \mathrm{NaCl}$ added to the batch has only $0.8 \mathrm{~g} \mathrm{KCl}$ in it; about $7 \%$ of the total salt present. Despite this, almost all potassium enters into the glass melt. Similarly, Base A-6 with $10 \mathrm{~g} \mathrm{NaCl}$ added to the batch has $4 \mathrm{~g} \mathrm{KCl}$ (equal to c. $2.1 \mathrm{~g} \mathrm{~K}$ ) in it, about $30 \%$ of the total salt present, but nearly $60 \%$ of the potassium goes into the glass (c. $1.2 \mathrm{~g} \mathrm{~K}$, equivalent to $1.5 \mathrm{wt} \% \mathrm{~K}_{2} \mathrm{O}$ in a batch of $100 \mathrm{~g}$ glass). At higher amounts of added sodium chloride the absolute figures change in favour of sodium uptake, that is less potassium enters the glass melt. From batch Base A- 6 with $4 \mathrm{~g} \mathrm{KCl}$ and $50 \mathrm{~g}$ added $\mathrm{NaCl}$, only $0.6 \mathrm{wt} \% \mathrm{~K}_{2} \mathrm{O}$ enter the glass, compared to $2.6 \mathrm{wt} \%$ in Base A-6 with no added $\mathrm{NaCl}$. The proportional uptake of potassium, however, is still much higher than that of sodium. In A-6 with $50 \mathrm{~g}$ added $\mathrm{NaCl}$, only about $7 \%$ of the total salt in the batch is $\mathrm{KCl}(4 \mathrm{~g}$ out of a total of $54 \mathrm{~g}$ salt), while the amount of $\mathrm{K}_{2} \mathrm{O}(0.6 \mathrm{wt} \%)$ in the glass is almost $25 \%$ of the maximum possible $(2.6 \mathrm{wt} \%)$. It appears that under these experimental conditions and at lower salt concentrations, potassium has a much stronger preference for the glass than for the salt phase.

The following sets of experiments (Series 2-5 to 2-7) tested the uptake of alkali metals from the salt phase when potassium chloride is added rather than sodium chloride. Here, the situation is very different from the previous set (Table 2, 3). The potash concentration in the glass in some cases even surpassed the soda concentrations, despite all carbonate in the batch being soda ash. The amount of potassium that goes into the glass phase increases as the additional amount of $\mathrm{KCl}$ increases. Notably, as in the previous series, the amount of chlorine in the glass remains near constant, at around 1.0 to $0.7 \mathrm{wt} \% \mathrm{Cl}$. Since the excess amount of chlorine can not escape as chlorine gas into the air during the firing but forms a well developed galle layer, it has to bond with another metal to form the excess salt phase. As before, magnesia and lime concentrations in these glasses remain almost unchanged, 
while the soda content decreases massively. Thus, there is a very clear interaction between the glass-forming system on the one hand and the salt system on the other, with a strong ion exchange that is restricted to the alkali metals.

The uptake of potash in the glass melt is not linear with increasing potassium chloride. There is only a short steep direct correlation where all potassium added as chloride enters the glass, up to about 2 to $3 \mathrm{wt} \%$ potash (Series 2-1, see Fig. 4), equivalent to the concentration range where almost all chlorine present is absorbed into the glass melt. Once the glass is in equilibrium with galle ('saturated in chlorine'), the uptake of potash as a proportion of the potassium chloride offered becomes less, and has to be balanced by an equivalent loss of soda from the glass system. In our experiments there seems to be a maximum content of potassium of 10-11 wt\% (Fig. 4), while the amount of sodium in the glass decreases accordingly, keeping the total molar alkali content near constant. The experiments did not explore the effect of even higher concentrations of potassium chloride, as higher salt to glass ratios were considered unrealistic in ancient glassmaking practice.

At about $50 \mathrm{~g}$ added potassium chloride (equivalent to about $32 \mathrm{~g} \mathrm{~K}_{2} \mathrm{O}$ ) and about $30 \mathrm{~g}$ soda ash (equivalent to about $17 \mathrm{~g} \mathrm{Na}_{2} \mathrm{O}$ ) in the batch (Base A-4 and A-5 with $50 \mathrm{~g}$ added $\mathrm{KCl}$ each), the resulting glass has equal amounts of about $10 \mathrm{wt} \%$ each potash and soda. While there is twice as much potassium expressed as oxide in the batch than sodium expressed as oxide, there are only equal amounts of potash and soda in the resulting glass. In other words, less than one third of the potassium offered as chloride enters the glass melt, while more than half of the sodium offered as soda ash goes into the glass. Accordingly, ignoring any loss by evaporation, more than two thirds of the potassium stay in the salt melt, and less than half of the sodium goes into the salt phase. Under these conditions, it appears that potassium has a preference for the salt phase, contrary to the result from the previous experiments (Series 2-2 to 2-4). 
A comparison of the ratio soda to potash in the batch (using total alkali oxide equivalents for chloride content) and the resulting glass is given in Table 4. It shows over a wide range of ratios that the soda content in the glass is higher than in the batch, by a factor typically of 1.2 to 1.8 , with the exception of the (almost salt-free) series $2-1$, where it remains unchanged within the limits of analytical uncertainty. The enrichment appears stronger in those experiments which had a higher amount of chloride added; however, further work is necessary to explore whether this is a systematic pattern or an over-interpretation of general noise in the data.

In summary, these series of experiments clearly demonstrate that alkali metal ion exchanges take place during glass-forming reactions, resulting in systematic and consistent differential partitioning of alkali ions between the silica-rich glass melt and the chlorine-based salt melt. However, the full details of the relative preference of the two alkali metals for the two systems are still unclear, but seem to favour potash uptake by the silicate melt at low concentrations and by the chloride melt at higher concentrations.

Analysis of the chlorine contents of the glasses are also interesting (Table 2); overall, they are superficially similar to each other, ranging from as low as $0.7 \mathrm{wt} \%$ to a maximum of $1.8 \mathrm{wt} \%$ in our experiments. However, they are not correlated to the total amount of salt added to the batch; the lowest levels of $\mathrm{Cl}$ were actually found in Series 2-7, which contained the highest amount of added salt and the lowest soda content in the resulting glass. This is confirming earlier observations that chlorine solubility is primarily governed by glass composition rather than the total amount of salt present in the batch (Bateson and Turner 1939). 
The results above indicate that the compositions of the glass phase, whose volume and recipe was kept constant throughout the series except for the variable amounts of chlorides added, were almost identical (Table 2), except for their sodium and potassium content. Despite the presence of large excess amounts of alkali chloride(s) in the batch, chlorine levels throughout the series remained below about $1.5 \mathrm{wt} \%$ in soda-rich glasses, and even below $1 \mathrm{wt} \%$ in glasses with less than about $12 \mathrm{wt} \%$ soda. This confirms the earlier observation that there is a chemically controlled limit of chlorine in the glass, and any excess amount of chlorine will form a separate salt phase that floats on top of the glass melt, and can be easily separated from it. At equilibrium conditions, the metal ions necessary to form this salt phase are taken from the total batch and not just the added chlorides. It is important to note that during the glass-forming process significant interaction between the glass-forming components and the salt phase occurs. These interactions and ion exchanges, however, are limited to the alkali metals. There is no noticeable change in the earth alkali concentrations in any of the experiments here, nor was any calcium or magnesium found in the XRF analyses of the salt phase after the reactions had occurred. This demonstrates that the presence of a salt phase in the batch has a strong and systematic influence on the alkali composition of the forming glass. The salt phase within the initial batch acts as a buffer or reservoir that can provide alkali metal ions as well as receive them from the glass melt. Thus, the Two Melt Model is highly relevant when considering the alkali oxide content in archaeological glasses made from salt-rich raw materials.

Adding increasing quantities of potassium chloride to the glass batch instead of sodium chloride confirms the picture of free interaction between the two melt systems, with large quantities of potassium going into the glass melt as potash, and matching amounts of sodium going into the salt phase even if there is no sodium chloride originally present in the batch. In other words, sodium and potassium can coexist in various ratios in the two 
melt systems and exchange relatively freely between the two, but the total molar content of alkalis $\left(\mathrm{Na}_{2} \mathrm{O}+\mathrm{K}_{2} \mathrm{O}\right)$ in the glass is kept similar to the total molar alkali carbonate content in the batch. This may appear surprising since the non-stoichiometric glass structure can absorb a very wide range of alkali oxide to silica ratios, and therefore should be able to increase alkali oxide contents in the glass when more alkali metal ions are available in the batch. However, the molar ratio between alkali metals and chlorine in the salt phase has to be kept constant at $1(\mathrm{KCl}$ or $\mathrm{NaCl}$, or any mixture in between), and there is no significant evaporation loss of chlorine at temperatures below c. $1400{ }^{\circ} \mathrm{C}$ (Gerth et al. 1998). Therefore, the soda content in the glass is reduced proportionately to the increase in potash when an excess amount of $\mathrm{KCl}$ is present, even if all the sodium is introduced as $\mathrm{Na}_{2} \mathrm{CO}_{3}$ and when this is the only alkali carbonate form present in the batch. The total alkali amount in the glass is determined by the molar amount of reactive carbonate plus a small amount of absorbed alkali chloride, that is, by the bulk batch composition, but not the phase species present in the batch. Contrary to the assumption made by Barkoudah and Henderson (2006: 311, 315, 319) and Tite et al. (2006: 1288), the ratio of soda to potash within the glass, therefore, is not equal the ratio of alkali oxides present as carbonates, but is a function of the total alkali ratio in the batch, modified by the relative proportion of chloride to carbonate. Both, alkali ratio in the overall batch and molar ratios carbonate to chloride, are relevant factors here. Our experiments indicate that the weight percent soda to potash ratio in the glass is typically between 1.2 and 1.8 times the total soda to potash ratio in the batch (Table 4). There is potentially a stronger shift of ratios, i.e. a stronger relative soda enrichment in the glass, for higher chlorine levels in the batch, but more experiments are needed to test this hypothesis.

Using the experimental data to illustrate the potential effect of alkali chloride content in theoretical plant ash batches on the final glass gives some interesting observations. For this, we focus on the glass produced from batch Base A-6 as is, and with additional $20 \mathrm{~g}$ of $\mathrm{NaCl}$ and $20 \mathrm{~g}$ of $\mathrm{KCl}$, respectively (Table 5). The difference in potash content between the 
first two is similar to the difference in potash between typical LBA glasses from Egypt and the cobalt-blue glasses, characterised by their much lower potash content (Lilyquist and Brill 1993). Similarly, the somewhat higher level of potash in Mesopotamian glasses compared to Egyptian glasses could be as easily explained by a systematically lower chloride content in the Mesopotamian plant ash batches as by the use of systematically different plant ashes.

In a recent paper Barkoudah and Henderson (2006: 311) state that 'If most of the potassium is in unreactive form, such as $\mathrm{KCl}$, ashes with a mixed-alkali composition could still be used for making soda-lime-silica glass, with $\mathrm{KCl}$ forming part of the scum on the glass or being volatilized', with further such statements on page 315 and 319. However, we have found here that the addition of $20 \mathrm{~g} \mathrm{KCl}$ to our standard batch, comprising only soda ash as carbonate, moves the alkali ratio of the forming glass to one very similar to the mixed alkali glasses known from LBA Frattesina, in northern Italy (Angelini et al. 2004). This is not to suggest that the Frattesina glasses are based on the same or similar plant ashes as the Egyptian LBA glasses; their alkali earth oxide content, at around $2-4 \mathrm{wt} \%$ combined $\mathrm{CaO}$ and $\mathrm{MgO}$, is too different for that and more consistent with a mineral flux. We simply want to illustrate the potential magnitude of potash contribution to the glass from $\mathrm{KCl}$ in the batch.

\section{Discussion and conclusion}

The research presented here indicates that the final alkali content of Near Eastern LBA glass is typically not a direct reflection of the alkali ratio in the plant ash used, whether expressed as total alkali ratio or after determination of alkali carbonates only. Instead, several separate factors work together in determining the final total alkali content and alkali ratio in the glass. These include the original amount of reactive alkali compounds in the plant ash relative to the silica in the batch, the total alkali ratio in the plant ash composition, and the proportion of chlorides and other non-reactive salts in the ash. Few of 
these are likely to be directly controlled by the ancient artisans making the glass, who had no means to determine or influence the carbonate to chloride ratio in the plant ash. Differences in these batch parameters may reflect ashes of different plant species being used, or different chemistries or salinities of the soils in which the plants grew; thus, the chemical composition of the glass can reflect human choices (plants selected for ashing) as well as geographical pattern (soil compositions), and it is likely that a combination of these cultural and regional signatures determine the final glass composition. The initial alkali ratio of the batch is then shifted to higher soda levels in the glass relative to potash once sufficient chloride is present to form a separate melt phase. The presence of large quantities of chlorides during the initial glass-making stage at LBA Pi-Ramesse is demonstrated by the regular discolouration of the ceramic of the reaction vessels found at Qantir (Fig. 5). This discoloration, also seen in some crucibles, has been experimentally shown to occur only in the presence of large amounts of chlorides in the primary glass batch (in the order of ten percent or more; Merkel and Rehren 2007; Rehren and Pusch 2007, 2008).

It is impossible for us to quantify the amount of chlorides present in the LBA glass batches; analyses of plant ashes by Brill (1999a, 1999b) and Tite et al. (2006, 2007) indicate that they were considerable, and typically reaching tens of percent by weight. Thus, it is important to consider their presence when discussing systematic differences in potash concentrations in otherwise very similar glasses, such as the slightly higher potash content of most Mesopotamian glass compared to Egyptian glass (see Shortland et al. 2007: 784-785; Table 2), and the sharply lower potash content of most cobalt-blue (and some other) glasses (Lilyquist and Brill 1993). Whether the latter is due to the use of a particularly potash-poor plant ash, possibly harvested in the Wadi Natrun with its soda-dominated soils, or is due to the addition of quantities of salt together with the cobalt colorant, remains to be seen. At present, we simply stress the strong and systematic effect which the naturally present chlorides have on the alkali content and ratios in the glass melt. Selecting the same plant species for ashing (=constant behaviour of the artisan) may result 
in different glass compositions, depending on the alkali ratio and salt content in the soil in which the plants grew (=variable composition of the finished glass). Thus, the long known tight clustering of culturally defined glass groups reflect both the consistent behaviour of the artisans and the melting properties of the glass-forming system; the differences in alkali concentrations between such groups and sub-groups can be either due to differences in raw materials, or particular preparation steps, for instance related to colorant additions or the treatment of plant ashes or intermediate glasses to remove less reactive components.

\section{Acknowledgements}

We are indebted to Kevin Reeves, Wolfson Archaeological Sciences Laboratories at the UCL Institute of Archaeology, for the microprobe analyses of the glass samples, and to the staff at the Department of Engineering Materials in Sheffield (MARCUS) for providing us with the glass raw materials, and excellent crucibles. Thanks are due to the Mellon Foundation for supporting Dr Tanimoto's current post, and our colleagues in the Department of Conservation and Scientific Research of the British Museum for their help and support. Comments by three anonymous referees, and further comments by Ian Freestone, have greatly improved the manuscript and are gratefully acknowledged. All remaining shortcomings are entirely ours.

\section{References:}

Angelini, I., Artioli, G., Bellintani, P., Diella, V., Gemmi, M., Polla, A., Rossi, A., 2004. Chemical analyses of Bronze Age glasses from Frattesina di Rovigo, Northern Italy. Journal of Archaeological Science 31, 1175-1184.

Barkoudah, Y., Henderson, J., 2006. Plant ashes from Syria and the manufacture of ancient glass: ethnographic and scientific aspects. Journal of Glass Studies 48, 297-321.

Bateson, H.M., Turner, W.E.S., 1939. A Note on the Solubility of Sodium Chloride in a 
Soda-Lime-Silica Glass. Journal of the Society of Glass Technology 23, 265-267.

Beerkens, R., 2001. Modeling the kinetics of volatilization from glass melts. Journal of American Ceramic Society 84, 1952-1960.

Beerkens, R., Verheijen, O., 2005. Reactions of alkali vapours with silica based refractory in glass furnaces, thermodynamics and mass transfer. Journal of Glass Technology 46, $371-382$

Brill, R., 1970. The chemical interpretation of the texts. In: L. Oppenheim, R. Brill, D. Barag and A. von Saldern (eds), Glass and Glassmaking in Ancient Mesopotamia. Corning Museum of Glass, Corning, New York, pp. 105-128.

Brill, R.H., 1999a. Chemical analysis of early glass, The catalogue, The Corning Museum of Glass, Corning.

Brill, R.H., 1999b. Chemical analysis of early glass, Table of analyses, The Corning Museum of Glass, Corning.

Busz, R., Sengle, G.., 1999. Zur Kieselkeramik - Begriffe, Werkstoffe, Verfahren. In: R. Busz and P. Gercke (eds), Türkis und Azur, Quarzkeramik im Orient und Okzident. Edition Minerva, Kassel, pp. 192-220.

Gerth, K., Wedepohl, K.H., Heide, K., 1998. Experimental Melts to Explore the Technique to Medieval Woodash Glass Production and the Chlorine Content of Medieval Glass Types. Chemie der Erde 58, 219-232.

Jackson, C.M., Smedley, J.W., 2004. Medieval and post-medieval glass technology: melting characteristics of some glasses melted from vegetable ash and sand mixtures. Glass Technology 45(1), 36-42.

Jackson, C.M., Booth, C.A., Smedley, J.W., 2005. Glass by design? Raw materials, recipes and compositional data. Archaeometry 47, 781-795. 
Köpsel, D., 2001. Solubility and vaporization of halides. Proceedings of International Congress on Glass, Edinburgh, Scotland, pp. 330.

Lilyquist, C., Brill, R.H., 1993. Studies in early Egyptian glass, The Metropolitan Museum of Art, New York.

Merkel, St., Rehren, Th., 2007. Parting layers, ash trays, and Ramesside glass-making: an experimental study. In: Pusch, E.B, Rehren, Th. (Eds.), Hochtemperatur-Technologie in der Ramses-Stadt - Rubinglas für den Pharao, Gerstenberg-Verlag, Hildesheim, pp. 201-221.

Oppenheim, L.A., Brill, R.H., Barag, D., Saldern, A.V., 1970. Glass and Glassmaking in Ancient Mesopotamia, The Corning Museum of Glass, New York.

Owen-Illinois Glass Company General Research Laboratory, 1944. Effect of substituting $\mathrm{MgO}$ for $\mathrm{CaO}$ on properties of typical soda-lime glasses. Journal of American Ceramic Society $27,221-25$.

Petrie, F.W.M., 1926. Glass in the early ages. Journal of the Society of Glass Technology $10,229-234$.

Rehren, Th., 1997. Ramesside glass-colouring crucibles. Archaeometry 39, 355-368.

Rehren, Th., 2000a. New aspects of ancient Egyptian glassmaking. Journal of Glass Studies 42, 13-23.

Rehren, Th., 2000b. Rationales in Old World Base Glass Compositions. Journal of Archaeological Science 27, 1225-1234.

Rehren, Th. 2008. A review of factors affecting the composition of early Egyptian glasses and faience: alkali and alkali earth oxides. Journal of Archaeological Science 35, $1345-1354$ 
Rehren, Th., Pusch, E.B., 2005. Late Bronze Age Glass Production at Qantir-Piramesses, Egypt. Science 308, 1756-1758.

Rehren, Th., Pusch, E.B, 2007. Glas für den Pharao - Glasherstellung in der Spätbronzezeit des Nahen Ostens. In: Wagner, G.. (Ed.), Fortschritte der Archäometrie. Springer-Verlag, Heidelberg etc., pp. 215-235.

Rehren, Th., Pusch, E.B, 2008. Crushed rock and molten salt? Some aspects of the primary glass production at Qantir / Pi-Ramesse. In: Jackson, C., Wager, E. (eds.), Vitreous Materials in the Late Bronze Age Aegean: A Window to the East Mediterranean World, Oxbow Books, Oxford, pp. PAGE \# still unknown

Sayre, E., Smith, R.W., 1974. Analytical studies of ancient Egyptian glass. In: Bishay, A. (Ed.), Recent advances in science and technology of materials: proceedings, Cairo Solid State Conference $2^{\text {nd }}, 1973$, Plenum Press, New York, pp. 47-70.

Schoer, B., Rehren, Th., 2007. The composition of glass and associated ceramics from Qantir. In: Pusch, E.B., Rehren, Th. (Eds.), Hochtemperatur-Technologie in der Ramses-Stadt - Rubinglas für den Pharao, Gerstenberg-Verlag, Hildesheim, pp. 171-199.

Shahid, K.A., Glasser, F.P., 1972. Phase equilibria in the glass forming region of the system $\mathrm{Na}_{2} \mathrm{O}-\mathrm{CaO}-\mathrm{MgO}-\mathrm{SiO}_{2}$. Physics and Chemistry of Glasses 13, 27-42.

Shortland, A.J., Rogers, N., Eremin, K., 2007. Trace element discriminants between Egyptian and Mesopotamian Late Bronze Age glasses. Journal of Archaeological Science 34, 781-789.

Shugar, A., Rehren, Th., 2002. Formation and composition of glass as a function of firing temperature. Glass Technology 43C, 145-150.

Tanimoto, S., 2007. Experimental study of Late Bronze Age glass-making practice. PhD Thesis, UCL Institute of Archaeology, University of London. 
Tite, M.S., Shortland, A.J., Maniatis, Y., Kavoussanaki, D., Harris, S.A., 2006. The composition of soda-rich and mixed alkali plant ashes used in the production of glass. Journal of Archaeological Science 33, 1284-1292.

Tite, M.S., Manti, P., Shortland, A.J., 2007. A technological study of ancient faience from Egypt. Journal of Archaeological Science 34, 1568-1583.

Turner, W.E.S., 1954a. Studies of Ancient Glasses and Glassmaking Processes. Part I. Crucibles and melting temperatures employed in ancient Egypt at about 1370 B.C. Journal of the Society of Glass Technology 38, 436-444.

Turner, W.E.S., 1954b. Studies of Ancient Glasses and Glassmaking Processes. Part II. The Composition, Weathering Characteristics and Historical Significance of Some Assyrian Glasses of the Eighth to Sixth Centuries B.C. from Nimrud. Journal of the Society of Glass Technology 38, 445-456.

Turner, W.E.S., 1956a. Studies in Ancient Glasses and Glassmaking Processes. Part III. The Chronology of the Glassmaking Constituents. Journal of the Society of Glass Technology 40, 39-52.

Turner, W.E.S., 1956b. Studies in Ancient Glasses and Glassmaking Processes. Part V. Raw Materials and Melting Processes. Journal of the Society of Glass Technology 40, 277-300. 
Table 1

\begin{tabular}{|c|c|c|c|c|c|c|c|c|c|c|}
\hline & $\mathrm{Na}_{2} \mathrm{O}$ & $\mathrm{MgO}$ & $\mathrm{Al}_{2} \mathrm{O}_{3}$ & $\mathrm{SiO}_{2}$ & $\mathrm{CaO}$ & $\mathrm{K}_{2} \mathrm{O}$ & $\mathrm{SO}_{3}$ & $\mathrm{Cl}$ & Total & Description \\
\hline DGG 1 & 14.6 & 4.42 & 1.18 & 71.3 & 6.89 & $\mathbf{0 . 3 7}$ & $\mathbf{0 . 3 1}$ & $\mathbf{0 . 0 4}$ & $\mathbf{9 9 . 1}$ & As measured \\
\hline & 15.0 & 4.18 & 1.23 & 71.7 & 6.73 & 0.34 & 0.44 & 0 & & certified \\
\hline DGG 2 & 13.7 & 3.64 & 0.06 & 71.7 & 10.3 & 0.02 & 0.19 & 0.05 & 99.7 & As measured \\
\hline & 13.8 & 3.40 & 0.10 & 72.3 & 10.1 & 0.00 & 0.27 & 0 & & certified \\
\hline
\end{tabular}

Table 2

\begin{tabular}{|c|c|c|c|c|c|c|c|c|c|}
\hline $\mathrm{Na}_{2} \mathrm{O}$ & MgO & $\mathbf{A l}_{2} \mathbf{O}_{3}$ & $\mathrm{SiO}_{2}$ & $\mathrm{CaO}$ & $\mathbf{K}_{2} \mathbf{O}$ & $\mathrm{SO}_{3}$ & $\mathbf{C l}$ & Sample Description & \\
\hline 18.5 & 4.7 & 0.13 & 65.2 & 11.1 & 0.6 & 0.12 & 0.4 & Base A-4: $18.5 \mathrm{wt} \% \mathrm{Na}_{2} \mathrm{O} *, 0.5 \mathrm{wt} \% \mathrm{~K}_{2} \mathrm{O}^{*}$ & \multirow{3}{*}{$\begin{array}{c}\text { Series } \\
2-1\end{array}$} \\
\hline 16.3 & 4.5 & 0.08 & 66.1 & 11.0 & 1.7 & 0.13 & 1.2 & Base A-5: $16.2 \mathrm{wt} \% \mathrm{Na}_{2} \mathrm{O} *, 1.7 \mathrm{wt} \% \mathrm{~K}_{2} \mathrm{O} *$ & \\
\hline 14.4 & 4.4 & 0.06 & 67.5 & 10.6 & 2.6 & 0.13 & 1.2 & Base A-6: $14.5 \mathrm{wt} \% \mathrm{Na}_{2} \mathrm{O} *, 2.5 \mathrm{wt} \% \mathrm{~K}_{2} \mathrm{O} *$ & \\
\hline 16.3 & 5.2 & 0.08 & 67.3 & 10.6 & 0.5 & 0.12 & 1.5 & Base A-4 + 10 g NaCl & \multirow{3}{*}{$\begin{array}{c}\text { Series } \\
2-2\end{array}$} \\
\hline 18.5 & 5.1 & 0.06 & 63.9 & 11.1 & 1.1 & 0.11 & 1.5 & Base A $-5+10 \mathrm{~g} \mathrm{NaCl}$ & \\
\hline 14.7 & 4.4 & 0.08 & 67.7 & 9.4 & 1.5 & 0.11 & 1.3 & Base A- $6+\mathbf{1 0} \mathbf{g ~ N a C l}$ & \\
\hline 18.3 & 4.0 & 0.09 & 65.8 & 8.2 & 0.5 & 0.12 & 1.7 & Base A-4 + 20 g NaCl & \multirow{3}{*}{$\begin{array}{c}\text { Series } \\
2-3\end{array}$} \\
\hline 14.3 & 4.4 & 0.12 & 68.9 & 8.8 & 0.9 & 0.11 & 1.3 & Base A $-5+\mathbf{2 0} \mathbf{g ~ N a C l}$ & \\
\hline 15.2 & 4.5 & 0.09 & 67.0 & 9.5 & 1.2 & 0.12 & 1.3 & Base A- $6+\mathbf{2 0} \mathbf{g ~ N a C l}$ & \\
\hline 18.8 & 4.4 & 0.09 & 64.1 & 11.4 & 0.2 & 0.11 & 1.8 & Base A- $4+\mathbf{5 0} \mathbf{~ g ~ N a C l}$ & \multirow{3}{*}{$\begin{array}{c}\text { Series } \\
2-4\end{array}$} \\
\hline 17.0 & 5.0 & 0.09 & 66.3 & 10.3 & 0.4 & 0.11 & 1.5 & Base A- $5+\mathbf{5 0} \mathbf{~ g ~ N a C l}$ & \\
\hline 16.7 & 4.3 & 0.05 & 67.5 & 10.4 & 0.6 & 0.11 & 1.5 & Base A- $6+\mathbf{5 0} \mathbf{g ~ N a C l}$ & \\
\hline 14.6 & 4.7 & 0.09 & 66.1 & 9.4 & 4.3 & 0.12 & 1.0 & Base A- $4+10$ g KCl & \multirow{3}{*}{$\begin{array}{c}\text { Series } \\
2-5\end{array}$} \\
\hline 12.7 & 4.8 & 0.08 & 66.2 & 10.0 & 5.1 & 0.11 & 1.0 & Base A- $-5+10$ g KCl & \\
\hline 13.2 & 4.9 & 0.07 & 65.5 & 10.1 & 5.5 & 0.11 & 1.0 & Base A- $6+10$ g KCl & \\
\hline $\mathbf{1 1 . 6}$ & 3.9 & 0.07 & 67.5 & 9.5 & 6.8 & 0.11 & 1.0 & Base A- $4+20$ g KCl & \multirow{3}{*}{$\begin{array}{c}\text { Series } \\
2-6\end{array}$} \\
\hline 11.9 & 4.3 & 0.09 & 66.3 & 9.9 & 7.2 & 0.11 & 0.9 & Base $\mathrm{A}-5+\mathbf{2 0} \mathbf{g ~ K C l}$ & \\
\hline 10.4 & 3.5 & 0.09 & 68.9 & 8.7 & 7.8 & 0.11 & 0.8 & Base A- $-6+20$ g KCl & \\
\hline 11.3 & 4.4 & 0.08 & 62.0 & 10.3 & 10.1 & 0.11 & 0.8 & Base A- $4+50$ g KCl & \multirow{3}{*}{$\begin{array}{c}\text { Series } \\
2-7\end{array}$} \\
\hline 9.0 & 4.2 & 0.10 & 65.8 & 9.4 & 10.7 & 0.11 & 0.8 & Base A- $-5+50 \mathbf{g ~ K C l}$ & \\
\hline 7.6 & 4.1 & 0.05 & 67.4 & 8.4 & 11.2 & 0.11 & 0.7 & Base A- $6+\mathbf{5 0} \mathbf{~ g ~ K C l}$ & \\
\hline
\end{tabular}

$\mathrm{Na}_{2} \mathrm{O}^{*}, \mathrm{~K}_{2} \mathrm{O}^{*}$ : added as $\mathrm{Na}_{2} \mathrm{CO}_{3}$ and $\mathrm{KCl}$ respectively to the batch (100 g). 
Table 3

\begin{tabular}{|c|c|c|c|c|c|c|c|c|c|}
\hline \multirow[t]{2}{*}{ Base Batch* } & \multicolumn{4}{|c|}{$\begin{array}{l}\text { Amount of additional } \mathrm{NaCl} \\
\text { [wt\%] added to the batch } \\
(100 \mathrm{~g} / \mathrm{batch}) \\
\text { Series } 2-1 \text { to } 2-4 \text {. }\end{array}$} & \multicolumn{4}{|c|}{$\begin{array}{l}\text { Amount of additional } \mathrm{KCl} \\
\text { [wt\%] added to the batch } \\
(100 \mathrm{~g} / \mathrm{batch}) \\
\text { Series } 2-1,2-5 \text { to } 2-7 \text {. }\end{array}$} & \multirow[t]{2}{*}{ Note } \\
\hline & $\mathbf{0}$ & 10 & 20 & 50 & $\mathbf{0}$ & 10 & 20 & $\mathbf{5 0}$ & \\
\hline A-4 & 0.6 & 0.5 & 0.5 & 0.2 & 0.6 & 4.3 & 6.8 & 10.1 & includes $18.5 \mathrm{wt} \% \mathrm{Na}_{2} \mathrm{O}^{* *}, 0.5 \mathrm{wt} \% \mathrm{~K}_{2} \mathrm{O}^{* *}$ \\
\hline A-5 & 1.7 & 1.0 & 0.9 & 0.4 & 1.7 & 5.1 & 7.2 & 10.7 & includes $16.2 \mathrm{wt} \% \mathrm{Na}_{2} \mathrm{O}^{* *}, 1.7 \mathrm{wt} \% \mathrm{~K}_{2} \mathrm{O}^{* *}$ \\
\hline A-6 & 2.6 & 1.5 & 1.2 & 0.6 & 2.6 & 5.5 & 7.8 & 11.2 & includes $14.5 \mathrm{wt} \% \mathrm{Na}_{2} \mathrm{O}^{* *}, 2.5 \mathrm{wt} \% \mathrm{~K}_{2} \mathrm{O}^{* *}$ \\
\hline
\end{tabular}

Base Batch*: All the Base Batches have $65.0 \mathrm{wt} \% \mathrm{SiO}_{2}, 10.5 \mathrm{wt} \% \mathrm{CaO}$, and $5.0 \mathrm{wt} \% \mathrm{MgO}$.

$\mathrm{Na}_{2} \mathrm{O}^{* *}, \mathrm{~K}_{2} \mathrm{O}^{* *}$ : added as $\mathrm{Na}_{2} \mathrm{CO}_{3}$ and $\mathrm{KCl}$ respectively to the batch $(100 \mathrm{~g} / \mathrm{batch})$.

Table 4

\begin{tabular}{|c|c|c|c|c|}
\hline $\begin{array}{c}\text { alkali ratios in } \\
\text { glass }\end{array}$ & $\begin{array}{c}\text { alkali ratios in } \\
\text { batch }\end{array}$ & \multirow{2}{*}{$\begin{array}{l}\mathrm{Na}_{2} \mathbf{O}_{\text {glass }} / \\
\mathrm{Na}_{2} \mathbf{O}_{\text {batch }}\end{array}$} & \multirow[t]{2}{*}{ Sample Description } & \multirow{5}{*}{$\begin{array}{c}\text { Series } \\
2-1\end{array}$} \\
\hline $\mathrm{Na}_{2} \mathrm{O}_{\text {glass }} / \mathrm{K}_{2} \mathrm{O}_{\text {glass }}$ & $\mathrm{Na}_{2} \mathrm{O}_{\text {batch }} / \mathrm{K}_{2} \mathrm{O}_{\text {batch }}$ & & & \\
\hline 30.8 & 37.0 & 0.8 & Base A-4: 18.5 wt $\% \mathrm{Na}_{2} \mathrm{O} *, 0.5 \mathrm{wt} \% \mathrm{~K}_{2} \mathrm{O} *$ & \\
\hline 9.6 & 9.5 & 1.0 & Base A-5: $16.2 \mathrm{wt}^{2} \% \mathrm{Na}_{2} \mathrm{O} *, 1.7 \mathrm{wt} \% \mathrm{~K}_{2} \mathrm{O} *$ & \\
\hline 5.5 & 5.8 & 0.9 & Base A-6: $14.5 \mathrm{wt} \% \mathrm{Na}_{2} \mathrm{O} *, 2.5 \mathrm{wt} \% \mathrm{~K}_{2} \mathrm{O} *$ & \\
\hline 32.6 & 47.6 & 0.7 & Base A-4 + 10 g NaCl & \\
\hline 16.8 & 12.6 & 1.3 & Base A-5 + 10 g NaCl & Series \\
\hline 9.8 & 7.9 & 1.3 & Base A-6 + 10 g NaCl & \\
\hline 36.6 & 58.2 & 0.6 & Base A-4 +20 g NaCl & \\
\hline 15.9 & 15.8 & 1.0 & Base A-5 +20 g NaCl & $\begin{array}{l}\text { Series } \\
4\end{array}$ \\
\hline 12.7 & 6.0 & 2.1 & Base A-6 +20 g NaCl & \\
\hline 94.0 & 90.0 & 1.0 & Base A-4 + 50 g NaCl & \\
\hline 42.5 & 25.1 & 1.7 & Base A-5 + 50 g NaCl & Series \\
\hline 27.8 & 16.4 & 1.7 & Base A- $6+\mathbf{5 0}$ g NaCl & \\
\hline 3.4 & 2.7 & 1.3 & Base A-4 + 10 g KCl & \\
\hline 2.5 & 2.0 & 1.3 & Base A-5 + 10 g KCl & $\begin{array}{l}\text { Series } \\
2-5\end{array}$ \\
\hline 2.4 & 1.6 & 1.5 & Base A-6 + 10 g KCl & \\
\hline 1.7 & 1.4 & 1.2 & Base A-4 + 20 g KCl & \\
\hline 1.7 & 1.1 & 1.5 & Base A-5 + 20 g KCl & $\begin{array}{c}\text { Series } \\
2-6\end{array}$ \\
\hline 1.3 & 1.0 & 1.3 & Base A-6 + 20 g KCl & \\
\hline 1.1 & 0.6 & 1.8 & Base A-4 + 50 g KCl & \\
\hline 0.8 & 0.5 & 1.6 & Base A-5 + 50 g KCl & $\begin{array}{c}\text { Series } \\
2-7\end{array}$ \\
\hline 0.7 & 0.4 & 1.8 & Base A-6 + 50 g KCl & \\
\hline
\end{tabular}

$\mathrm{Na}_{2} \mathrm{O}^{*}, \mathrm{~K}_{2} \mathrm{O}^{*}$ : added as $\mathrm{Na}_{2} \mathrm{CO}_{3}$ and $\mathrm{KCl}$ respectively to the batch $(100 \mathrm{~g})$. 
Table 5

\begin{tabular}{|c|c|c|c|c|c|c|c|c|}
\hline $\mathbf{N a}_{2} \mathrm{O}$ & $\mathbf{M g O}$ & $\mathbf{A l}_{\mathbf{2}} \mathbf{O}_{\mathbf{3}}$ & $\mathbf{S i O}_{\mathbf{2}}$ & $\mathbf{C a O}$ & $\mathbf{K}_{\mathbf{2}} \mathrm{O}$ & $\mathbf{S O}_{\mathbf{3}}$ & $\mathbf{C l}$ & Sample Description \\
\hline $\mathbf{1 4 . 4}$ & 4.4 & 0.06 & 67.5 & 10.6 & $\mathbf{2 . 6}$ & 0.13 & 1.2 & Base A-6: $14.5 \mathrm{wt} \% \mathrm{Na}_{2} \mathrm{O}^{*}, 2.5 \mathrm{wt}^{\circ} \mathrm{K}_{2} \mathrm{O}^{*}$ \\
\hline $\mathbf{1 5 . 2}$ & 4.5 & 0.09 & 67.0 & 9.5 & $\mathbf{1 . 2}$ & 0.12 & 1.3 & Base A-6 $+\mathbf{2 0} \mathbf{g ~ N a C l}$ \\
\hline $\mathbf{1 0 . 4}$ & 3.5 & 0.09 & 68.9 & 8.7 & $\mathbf{7 . 8}$ & 0.11 & 0.8 & Base A-6 $+\mathbf{2 0} \mathbf{g ~ K C l}$ \\
\hline
\end{tabular}

$\mathrm{Na}_{2} \mathrm{O}^{*}, \mathrm{~K}_{2} \mathrm{O}^{*}$ : added as $\mathrm{Na}_{2} \mathrm{CO}_{3}$ and $\mathrm{KCl}$ respectively to the batch $(100 \mathrm{~g})$. 


\section{Captions for Figures and Tables (Satoko Tanimoto \& Thilo Rehren)}

Fig. 1. The SLS ternary system with $5 \mathrm{wt} \% \mathrm{MgO}$. The round spot shows Base A composition. Typical compositions of LBA Egyptian glasses range in the grey area.

Fig. 2. Spatial separation of glass and residual salt material (clear glass phase can be seen below the residual salt material). (a) Seen from above and (b) in cross section.

Fig. 3. Potash content in the glass with increasing amount of $\mathrm{NaCl}$ in the batch. The minimum potash content in the glass is approximately $0.5 \mathrm{wt} \%$.

Fig. 4. Alkali oxide contents in the glass with increasing amount of $\mathrm{KCl}$ added to the batch. Sodium is added as carbonate and potassium as chloride (expressed here as potassium oxide equivalent to match the glass analyses).

Fig. 5. Characteristic discoloration of the Nile silt ceramic of a reaction vessel beneath the parting layer (grey thin layer to the left). See Rehren and Pusch $(2007,2008)$ for a detailed discussion of the formation of this discoloration, and Merkel and Rehren (2007) for its experimental reconstruction.

Table 1: Comparison of certified and measured compositional values for two reference glasses, in weight percent. DGG = Deutsche Glastechnische Gesellschaft.

Table 2. Compositions of glass melts with various alkali concentrations. [Average of multiple EPMA analyses per sample, expressed in $\mathrm{wt} \%]$.

This table also has a note at the bottom of the table:

$\mathrm{Na}_{2} \mathrm{O}^{*}, \mathrm{~K}_{2} \mathrm{O}^{*}$ : added as $\mathrm{Na}_{2} \mathrm{CO}_{3}$ and $\mathrm{KCl}$ respectively to the batch.

Table 3. Potassium oxide contents of different glass melts with increasing amounts of additional alkalis added, either as $\mathrm{NaCl}$ or $\mathrm{KCl}$. [Average of multiple EPMA analyses per sample, expressed in $\mathrm{wt} \%$ ].

This table also has a note at the bottom of the table:

$\mathrm{Na}_{2} \mathrm{O}^{* *}, \mathrm{~K}_{2} \mathrm{O}^{* *}$ : added as $\mathrm{Na}_{2} \mathrm{CO}_{3}$ and $\mathrm{KCl}$ respectively to the batch.

Table 4. Comparison of total soda to potash ratios in glass (first column), batch including alkalis added as chlorides (second column), and enrichment factor of soda in glass over soda in batch (third column). High numerical values for soda/potash ratios are likely inaccurate due to analytical uncertainly for very low absolute potash values.

This table also has a note at the bottom of the table:

Base Batch*: All the Base Batches have $65.0 \mathrm{wt} \% \mathrm{SiO}_{2}, 10.5 \mathrm{wt} \% \mathrm{CaO}$, and $5.0 \mathrm{wt} \% \mathrm{MgO}$.

$\mathrm{Na}_{2} \mathrm{O}^{* *}, \mathrm{~K}_{2} \mathrm{O}^{* *}$ : added as $\mathrm{Na}_{2} \mathrm{CO}_{3}$ and $\mathrm{KCl}$ respectively to the batch.

Table 5. Comparison of glass resulting from batch Base A6 (top row), batch Base A6 with added sodium chloride (middle row) and batch Base A6 with added potassium chloride (bottom row). Note the differences in potash concentrations in the resulting glasses. [Average of multiple EPMA analyses per sample, expressed in $\mathrm{wt} \%$ ].

This table also has a note at the bottom of the table:

$\mathrm{Na}_{2} \mathrm{O}^{* *}, \mathrm{~K}_{2} \mathrm{O}^{* *}$ : added as $\mathrm{Na}_{2} \mathrm{CO}_{3}$ and $\mathrm{KCl}$ respectively to the batch. 


\section{Figure}

Click here to download high resolution image

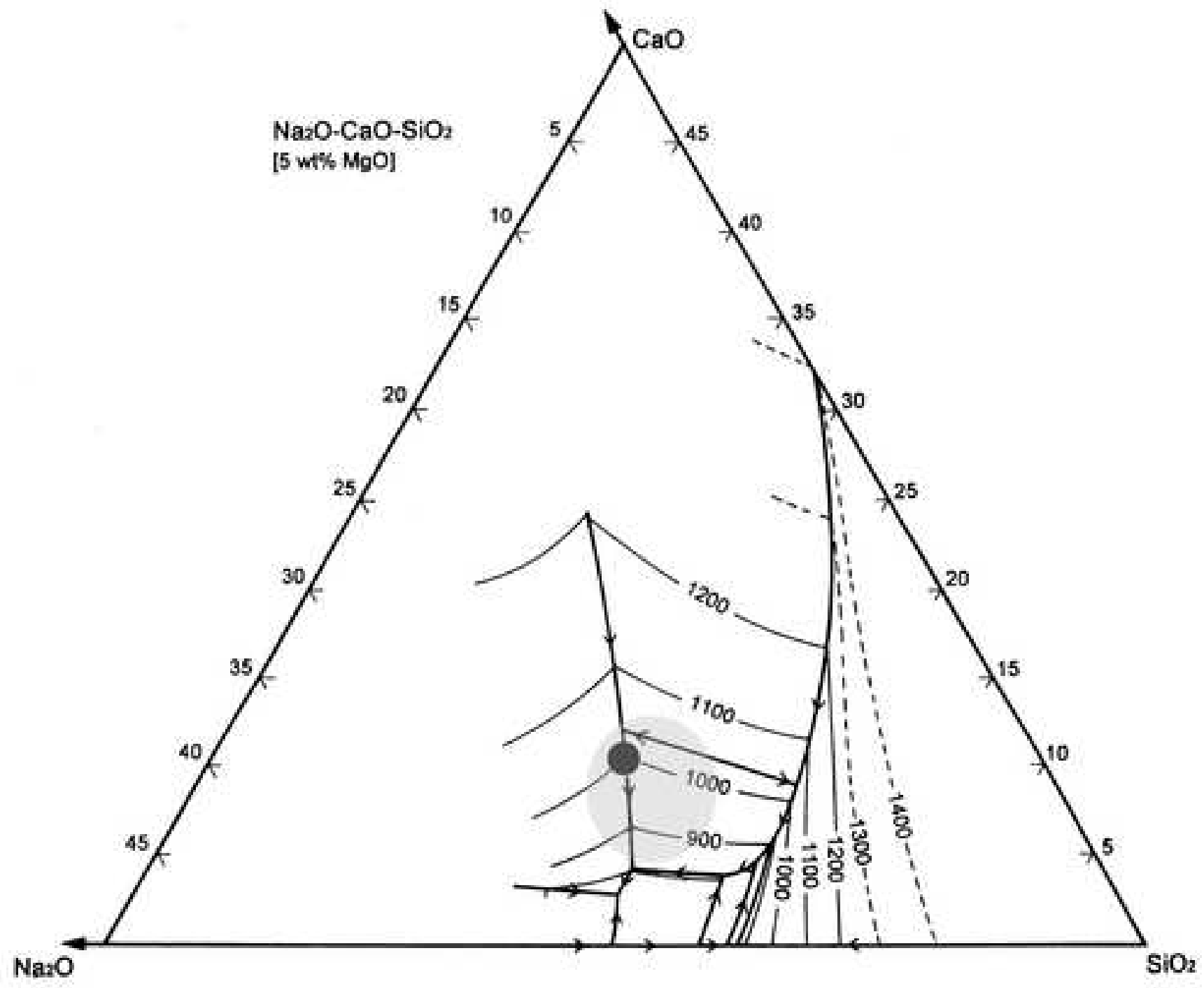


Click here to download high resolution image

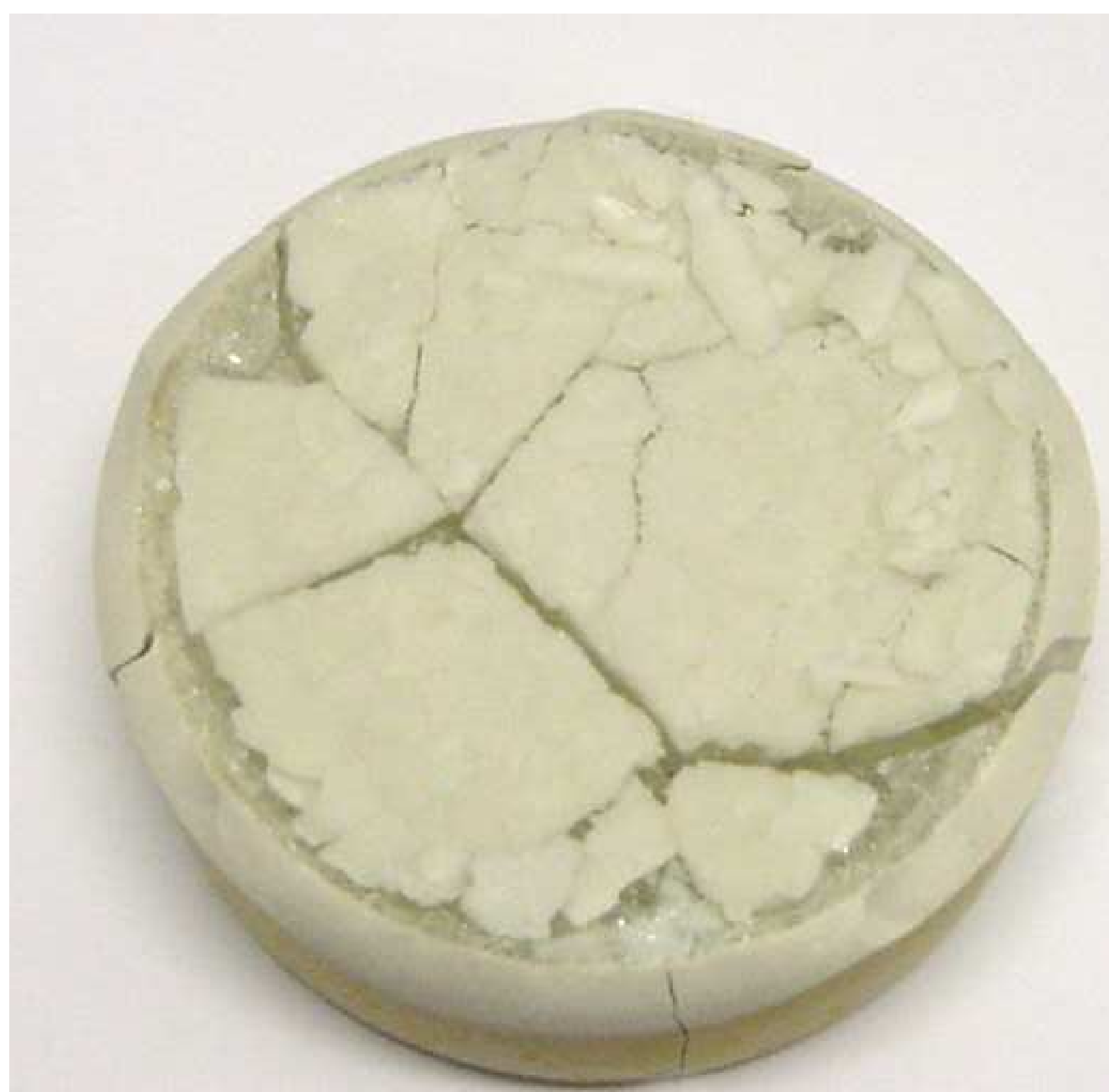




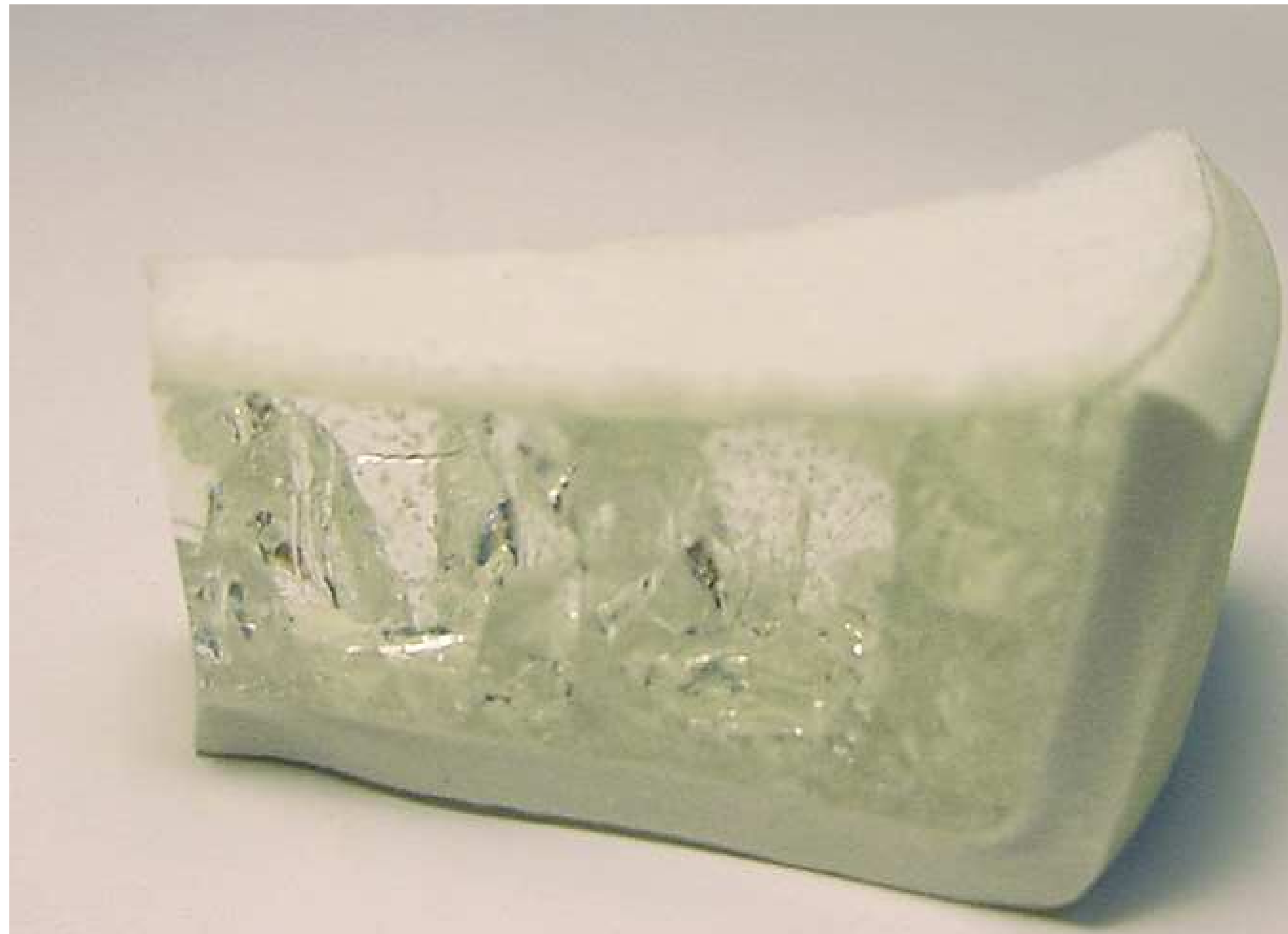




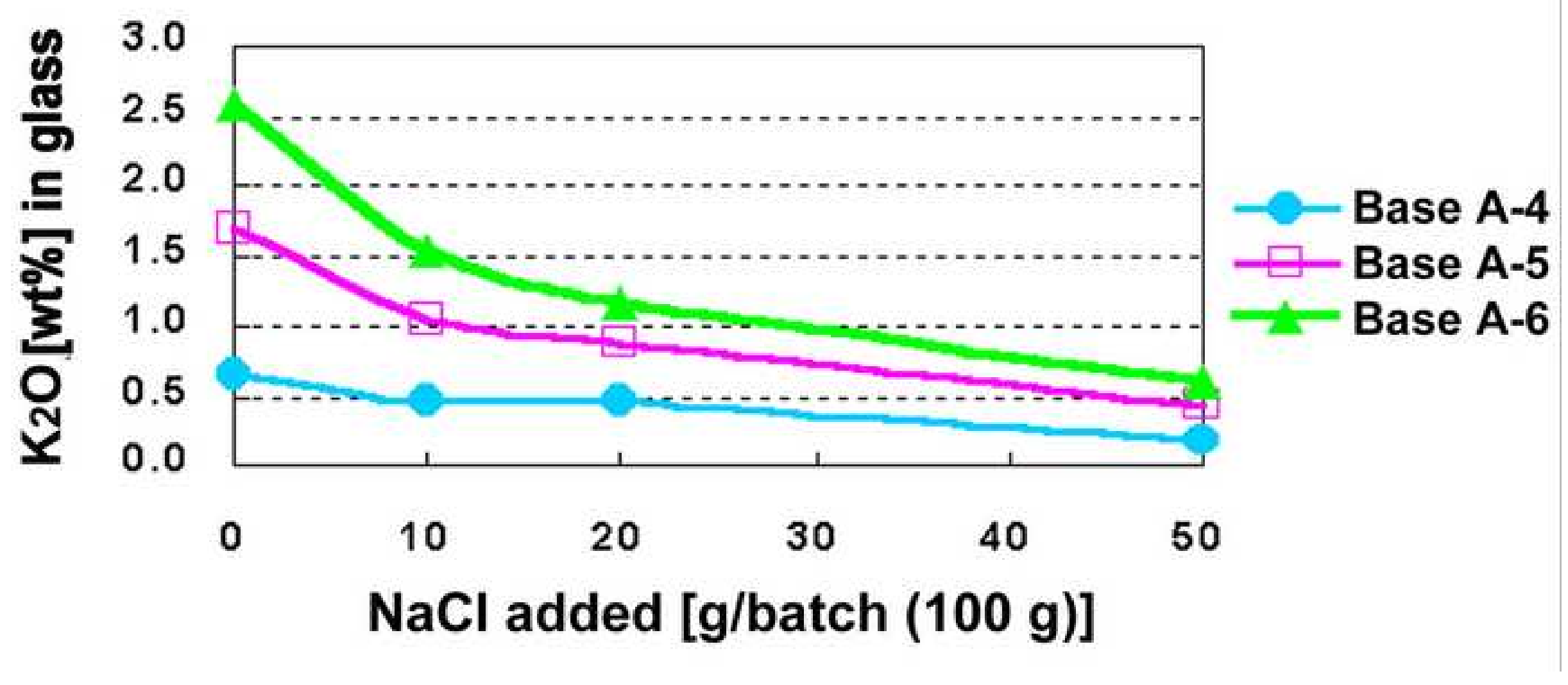




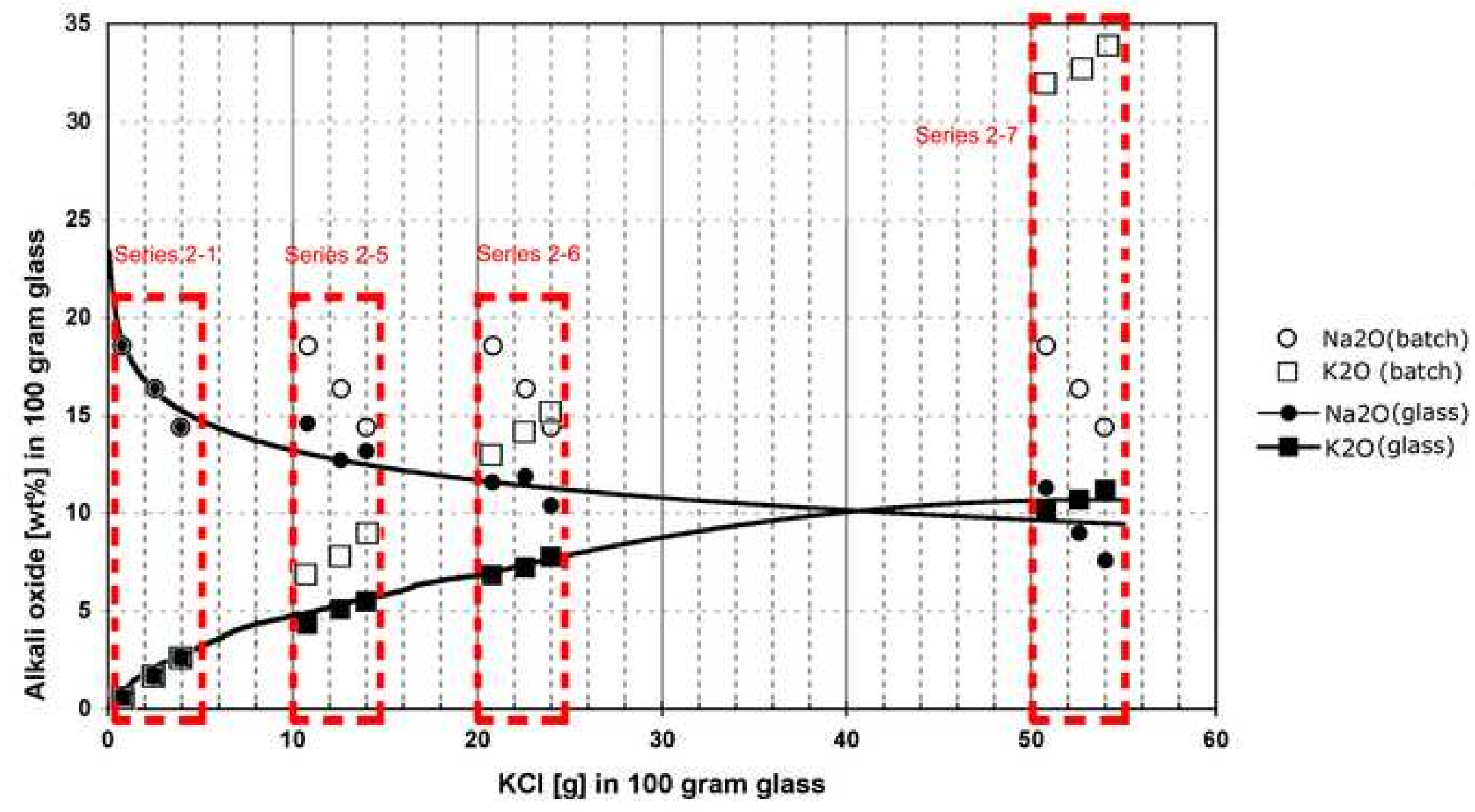


Figure
Click here to download high resolution image

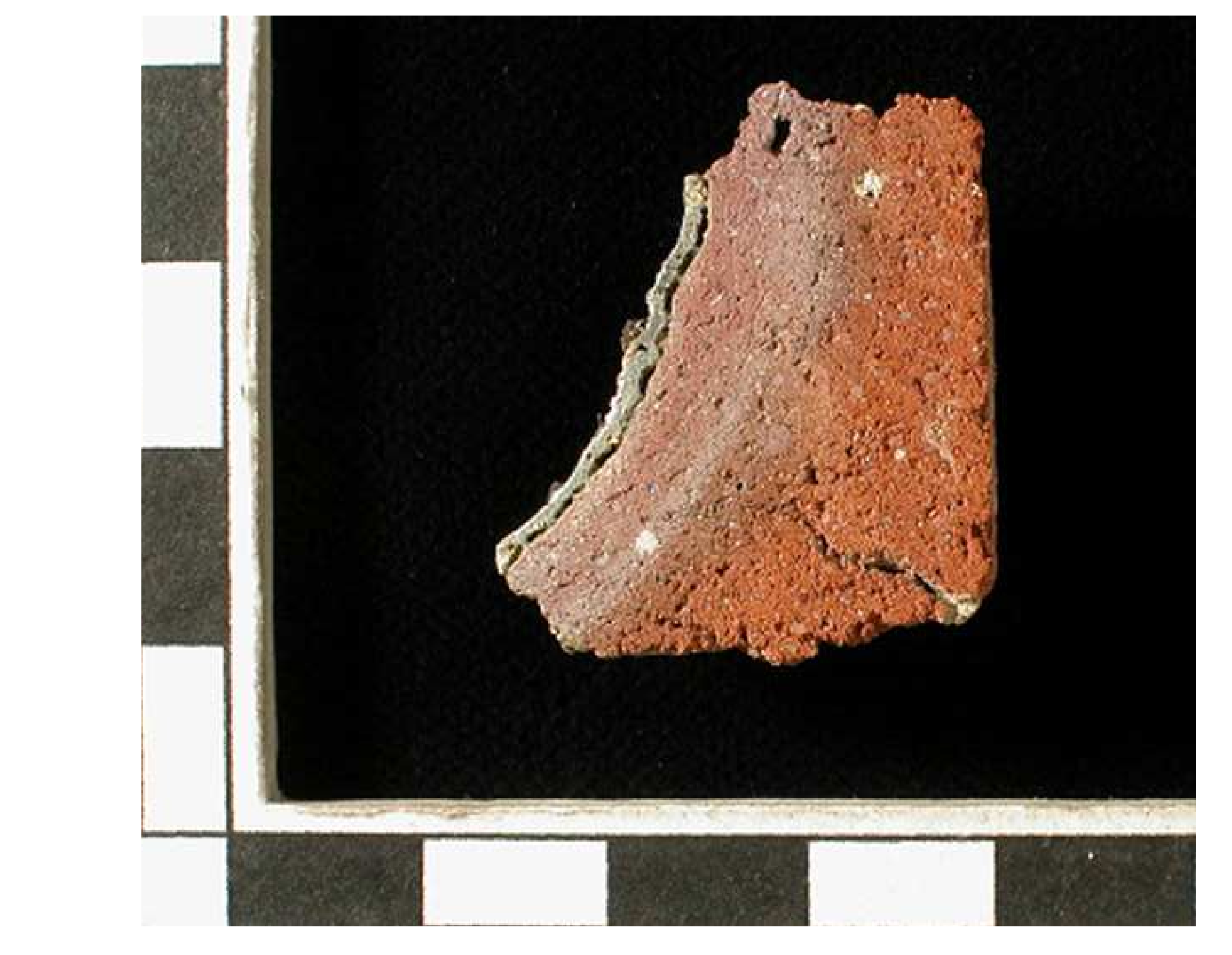

. 